\title{
EVALUATION OF THE RESULTS OF THE USE OF VEPTR IN PATIENTS WITH SCOLIOSIS
}

\author{
AVALIAÇÃO DOS RESULTADOS DA UTILIZAÇÃO DO VEPTR EM PACIENTES PORTADORES \\ DE ESCOLIOSE
} EVALUACIÓN DE LOS RESULTADOS DEL USO DE VEPTR EN PACIENTES CON ESCOLIOSIS

João Paulo Silva Araújo1', Marcos André Costa Ferreira1', André Flavio Freire Pereira1', Tulio Albuqueroue de Moura Rangel', Rodrigo Castro de Medeiros ${ }^{1}$, Luciano Temporal Borges Cabral $^{1}$

1. Hospital Getúlio Vargas, Spine Surgery Group, Recife, PE, Brazil.

\begin{abstract}
Objective: Evaluation of the results of the use of VEPTR (Vertical Expandable Prosthetic Titanium Rib - Synthes Spine Co. ${ }^{\circledR}$, West Chester, Pennsylvania, USA) as an option in spinal instrumentation without fusion in younger children with scoliosis, considering the complications inherent to spinal fusion in this age group. Methods: Sixteen (16) patients with scoliosis, regardless of etiology, with a mean age of 5.2 (3-8) years, were followed up by Spine Surgery Group at Hospital Getúlio Vargas, Recite-PE, and were submitted to surgical correction of the deformity using VEPTR, from April/2009 to July/2014. The survey was conducted through medical register review, and photographic and radiographic records, with the measurement of pre- and postoperative curves by the Cobb method. Results: The mean values of Cobb angle in the preoperative period, in the immediate postoperative period and after the last distraction were, respectively, $84.1^{\circ}\left(112^{\circ}-60^{\circ}\right), 55.4^{\circ}\left(92^{\circ}-16^{\circ}\right)$ and $64.4^{\circ}\left(100^{\circ}-16^{\circ}\right)$, with an average initial correction of $28.7^{\circ}(34.1 \%)$ and final correction of $19.7^{\circ}(23.4 \%)$. The mean follow-up was 23.1 (0-61) months with an average distraction of 3.1 (0-8). The complication rate in this study was $62.5 \%$. Conclusion: The VEPTR presented considerable correction rates of scoliosis curves in patients whose age contraindicate the spinal fusion methods. It is necessary to improve the technique and the implant itself in order to reduce complication rates, which can be considered relatively high, in addition to the conduction of more studies with longer follow-up to determine the actual efficacy of the implant and the maintenance of long-term correction.
\end{abstract}

Keywords: Scoliosis; Spinal fusion/Instrumentation; Spine; Prostheses and implants.

RESUMO

Objetivo: Avaliação dos resultados do uso do VEPTR (Vertical Expandable Prosthetic Titanium Rib - Synthes Spine Co. ${ }^{\circledR}$, West Chester, Pennsylvania, USA) como opção na instrumentação vertebral sem fusão em crianças mais jovens portadoras de escoliose, considerando as complicações inerentes à fusão vertebral nessa faixa etária. Métodos: Foram avaliados 16 (dezesseis) pacientes portadores de escoliose, independentemente da etiologia, e com média de idade de 5,2 (3 a 8) anos, acompanhados pelo Grupo de Cirurgia da Coluna Vertebral do Hospital Getúlio Vargas, Recife-PE, e submetidos à correção cirúrgica da deformidade por meio da utilização do VEPTR no período de abril/2009 a julho/2014. A pesquisa foi realizada por meio de revisão de prontuários, além de registros fotográficos e radiográficos, com a medida das curvas pré e pós-operatórias efetuadas pelo método de Cobb. Resultados: Os valores médios de Cobb pré-operatório, no pós-operatório imediato e após a última distração foram, respectivamente, $84,1^{\circ}\left(112^{\circ}-60^{\circ}\right), 55,4^{\circ}\left(92^{\circ}-16^{\circ}\right)$ e $64,4^{\circ}\left(100^{\circ}-16^{\circ}\right)$, com uma correção inicial média de $28,7^{\circ}(34,1 \%)$ e final de $19,7^{\circ}(23,4 \%)$. A média de acompanhamento foi de 23,1 (0 a 61) meses com a média de distrações de 3,1 (0 a 8). A taxa de complicações no presente estudo foi de 62,5\%. Conclusão: O VEPTR apresentou taxas de correção consideráveis das curvas escolióticas em pacientes cuja idade contraindica os métodos de fusão vertebral. Faz-se necessário aprimorar a técnica e o próprio implante a fim de reduzir as taxas de complicação, que podem ser consideradas relativamente elevadas, além da elaboração de um maior número de estudos com acompanhamento mais longo a fim de verificar a real eficácia do implante quanto à manutenção da correção a longo prazo.

Descritores: Escoliose; Fusão vertebral/Instrumentação; Coluna vertebral; Próteses e implantes.

\section{RESUMEN}

Objetivo: Evaluación de los resultados del uso de VEPTR (Vertical Expandable Prosthetic Titanium Rib - Synthes Spine Co. ${ }^{\circledR}$, West Chester, Pennsylvania, USA) como una opción en la instrumentación espinal sin fusión en niños más jóvenes con escoliosis, teniendo en cuenta las complicaciones inherentes a la fusión espinal en este grupo de edad. Métodos: Un total de dieciséis (16) pacientes con escoliosis, independientemente de su etiología, y con una edad media de 5,2 (3-8) años, acompañados por el Grupo de Columna Vertebral del Hospital Getúlio Vargas, Recife-PE, sometidos a la corrección quirúrgica de la deformidad mediante el uso de VEPTR de abril/2009 a julio/2014. La encuesta se realizó a través de revisión de las historias clínicas y los registros fotográficos y radiográficos, con la medición de las curvas pre y postoperatorias realizadas por el método de Cobb. Resultados: Los valores medios de Cobb, antes de la cirugía, en el postoperatorio inmediato y después de la última distracción fueron, respectivamente, $84,1^{\circ}\left(112^{\circ}-60^{\circ}\right), 55,4^{\circ}\left(92^{\circ}-16^{\circ}\right)$ y $64,4^{\circ}\left(100^{\circ}-16^{\circ}\right)$, con una corrección inicial promedio de $28,7^{\circ}(34,1 \%)$ y final de 19,7 (23,4\%). El promedio de seguimiento fue de 23,1 (0-61) meses, con un promedio de distracción de 3,1 (0-8). La tasa de complicaciones en este estudio fue del 62,5\%. Conclusión: EI VEPTR presentó considerables tasas de corrección de las curvas de escoliosis en pacientes cuya edad contraindica los métodos de fusión espinal. Es necesario mejorar la técnica y el propio implante a fin de reducir las tasas de complicaciones, que pueden considerarse relativamente altas, además de la realización de un mayor número de estudios con un seguimiento más largo para determinar la verdadera eficacia del implante y el mantenimiento de la corrección a largo plazo.

Descriptores: Escoliosis; Fusión vertebral//Instrumentación; Columna vertebral; Prótesis e implantes.

Study conducted at the Hospital Getúlio Vargas, Spine Surgery Group, Recife, PE, Brazil.

Correspondence: Rua Ministro Mirabeu da Cunha Melo, 1914, Apto 901, Natal, RN, Brazil. 59064-490. joaopaulo0607@gmail.com 


\section{INTRODUCTION}

The treatment of scoliosis in younger children has proven to be a major challenge, even when conducted by more experienced spine surgeons. During its evolution, especially in children with early onset scoliosis, this deformity tends to cause a deficit in thoracic development with a depletion of chest volume that can lead to thoracic insufficiency syndrome, a potentially fatal condition in which the chest becomes unable to support normal breathing or lung growth. ${ }^{1}$ Faced with this problem, therapeutic intervention aimed at correcting and stopping the progression of the deformity and preventing the occurrence of the associated complication is required.

Conservative treatment with orthotics or plaster casts is not invasive and maintains spinal movement and mobility. However, while it modestly prevents progression, it does not permit correction of the curves and it is even less effective with neuromuscular deformities, posing the additional risk of skin lesions in children with sensory deficit. However, surgical treatment, with its various different possibilities, enables proper correction of the deformity and prevents its progression. ${ }^{2}$

The surgical therapeutic arsenal ranges from vertebral fusion with or without instrumentation to spinal stabilization methods without fusion, such as the classical example using rods and hooks described by Harrington, ${ }^{3}$ or, more recently, to distraction systems like Growing Rods $^{4}$ and VEPTR (Vertical Expandable Prosthetic Titanium Rib - Synthes Spine Co. ${ }^{\circledR}$, West Chester, Pennsylvania, USA). ${ }^{5}$ We know that the use of spinal fusion systems to correct scoliosis in younger children, particularly in those younger than five years old, can lead to a short trunk, which can compromise respiratory function by up to $50 \%$ by the end of the growth period. ${ }^{6}$ Moreover, posterior spinal fusion can cause the so-called crankshaft phenomenon, requiring fusion of the associated anterior spine ${ }^{7}$ and increasing morbidity.

Harrington's initial description of spinal stabilization without fusion $^{3}$ led to the assembly of rods and hooks (Harrington rods) that enabled correction of deformity without the need to fuse vertebral elements, thereby avoiding harmful effects in younger children with scoliosis. However, it produced precarious results due to the partial fusion of the subperiosteal dissection of the paravertebral musculature performed during surgical access to the spine. The lack of external support protecting the rods in the technique described also caused displacement of the hooks and breakage of the rods, leading to the failure of the procedure. ${ }^{2}$ Despite the unsatisfactory results of Harrington's instrumentation, the idea of using systems to improve alignment of the vertebral axis without fusion persisted.

With the creation of distraction systems, it became possible to correct three-dimensional thoracic deformities associated with scoliosis in younger children by means of instrumentation without spinal fusion and without the failures observed in earlier methods like the Harrington rods. Our analysis was focused on VEPTR. This implant enables the treatment of spine deformities without arthrodesis by means of a series of stretchings, with fixation on the ribs, laminae, or pelvis.

The objective of this study was to evaluate the results obtained in correcting scoliotic curves by means of vertebral instrumentation without fusion using VEPTR in patients for whom corrective methods using vertebral fusion are contraindicated because of their age.

\section{MATERIALS AND METHODS}

This retrospective study initially evaluated 18 patients who had undergone implantation of VEPTR for the surgical correction of spinal deformity and were monitored by the Spinal Surgery Group of the Hospital Getúlio Vargas, Recife-PE, during the period from April 2009 to July 2014. One patient died in the immediate postoperative from hypovolemic shock and another underwent surgery for correction of a sagittal deformity and was excluded from the study. Thus, 16 patients with an average age of 5.2 years (3-8 years) were evaluated. The research was conducted by means of a review of medical records, including photographic and radiographic documentation, with pre- and postoperative curve measurements taken using the Cobb method and with the assistance of goniometry.
The implant evaluated in the surgical correction of scoliotic deformities, the VEPTR (Vertical Expandable Prosthetic Titanium Rib Synthes Spine Co ${ }^{\circledR}$, West Chester, Pennsylvania, USA), consists of a mechanical stabilization and distraction device with rib-rib, rib-lumbar vertebra, or rib-iliac bone connections, designed to correct the threedimensional thoracic deformities resulting from scoliosis through successive and periodic distractions, promoting improved pulmonary function and growth. ${ }^{8}$ (Figure 1) The rib-bone fixation alternative was the type of connection evaluated in our study.

The angles of the scoliotic curves were measured preoperatively, in the immediate postoperative period, and after subsequent distractions of the implant, using radiographs in AP and profile orthostatic incidences to obtain the values in degrees using the Cobb method.

The study was submitted to and approved by the Institutional Review Board as adhering to all relevant aspects of Resolution No. 169 of 10 October 1996 that establishes the regulatory guidelines for research involving human beings, guaranteeing the anonymity of the subjects (CNS [National Health Council], 1996).

The data were organized into Microsoft Excel ${ }^{\circledR}$ spreadsheets, handled statistically as simple percentages, and arranged in tables.

\section{RESULTS}

Of the sixteen patents included in the study, six (37.5\%) were male and ten (62.5\%) were female. Their average age at the time of surgery for implantation of the VEPTR, considered the same as the age at the start of follow-up, was 5.2 years (3-8 years). The data related to the etiology of the scoliosis are reported in Table 1. The angles of the curves in the pre- and immediate postoperative periods, as well as the initial correction values, are shown in Table 2 . The final correction values and Cobb angles, measured after the last distraction performed for each patient, together with the number of distractions and the follow-up time, are shown in Table 3. In this study, the average values in the preoperative, immediate postoperative, and following the last distraction were $84.1^{\circ}, 55.4^{\circ}$, and $64.4^{\circ}$ respectively. We obtained an average of 3.1 distractions (0-8) during an average follow-up of 23.1 months (0-61), defined as the time between the date of the surgery for implantation of the VEPTR and the last distraction performed. The average initial correction value was $28.7^{\circ}(34.1 \%)$ and the average final correction value was $19.7^{\circ}(23.4 \%)$. (Table 4 )

The complication rate in our study was $62.5 \%$. Patients 1,10 , and 12 developed loosening of the implant because of fractured ribs, 2 and 9 with exposure of the implant, 5 with junctional kyphosis, (Figure 2) 6 and 8 with infection of the surgical site, 7 with correction of lumbar lordosis (flat back), and 13 with respiratory insufficiency in the immediate postoperative period.

In patients 1, 10, and 12, the loosening of the implant caused by the fracture of the rib bound by the upper ring of the implant was resolved by a second posterior surgical approach to reposition it. In patients 2 and 9, the periodic application of bandages contributed to

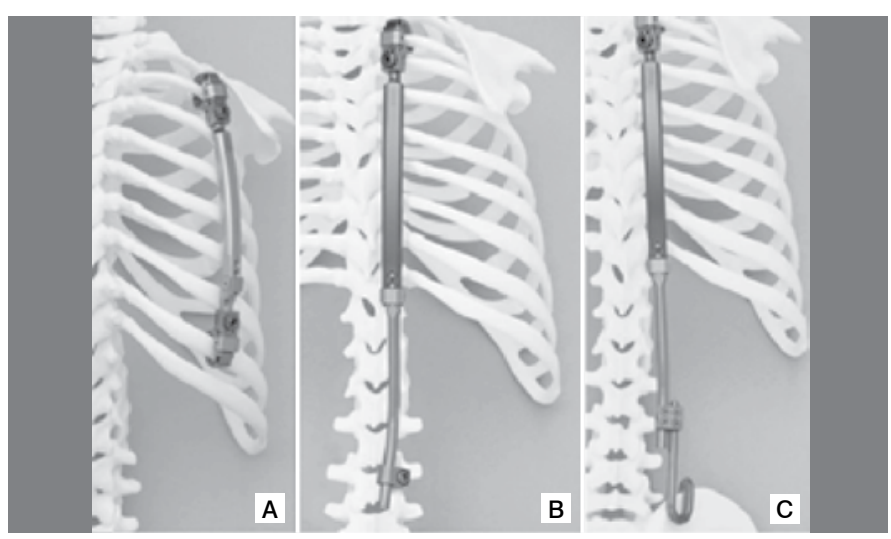

Figure 1. VEPTR fixation options. A) Rib-rib; B) Rib-lumbar vertebra; C) Rib-iliac bone (Source: VEPTR II - Vertical Expandable Prosthetic Titanium Rib II; Technique guide; Synthes Spine Co. $\left.{ }^{\circledR}\right) .{ }^{8}$ 
Table 1. General data.

\begin{tabular}{|c|c|c|c|c|}
\hline Patient & Sex & Age (years) & Etiology of the scoliosis & Curve \\
\hline 1 & $M$ & 8 & Myelomeningocele & Thoracic \\
\hline 2 & $M$ & 5 & Arthrogryposis & Thoracolumbar \\
\hline 3 & M & 4 & Cerebral palsy & Thoracolumbar \\
\hline 4 & $\mathrm{~F}$ & 7 & Congenital myopathy & Thoracolumbar \\
\hline 5 & $\mathrm{~F}$ & 3 & Congenital myopathy & Thoracolumbar \\
\hline 6 & $M$ & 8 & Myelomeningocele & Thoracolumbar \\
\hline 7 & M & 3 & Infantile idiopathic scoliosis & Thoracic \\
\hline 8 & $\mathrm{~F}$ & 4 & Cerebral palsy & Thoracolumbar \\
\hline 9 & $\mathrm{~F}$ & 4 & Juvenile idiopathic scoliosis & Thoracic \\
\hline 10 & $M$ & 8 & Cerebral palsy & Thoracic \\
\hline 11 & $\mathrm{~F}$ & 4 & Spinal muscular atrophy & Thoracolumbar \\
\hline 12 & $\mathrm{~F}$ & 3 & Moebius syndrome & Thoracic \\
\hline 13 & $\mathrm{~F}$ & 7 & Spinal muscular atrophy & Thoracolumbar \\
\hline 14 & $\mathrm{~F}$ & 5 & Juvenile idiopathic scoliosis & Thoracic \\
\hline 15 & $\mathrm{~F}$ & 6 & Cerebral palsy & Thoracic \\
\hline 16 & $\mathrm{M}$ & 4 & Myelomeningocele & Thoracolumbar \\
\hline
\end{tabular}

Table 2. Pre- and immediate postoperative Cobb measurements, initial correction of curve expressed in degrees and as a percentage.

\begin{tabular}{|c|c|c|c|}
\hline Patient & $\begin{array}{c}\text { Preoperative } \\
\text { Cobb }\end{array}$ & $\begin{array}{c}\text { Immediate } \\
\text { postoperative Cobb }\end{array}$ & Initial correction \\
\hline 1 & $104^{\circ}$ & $60^{\circ}$ & $44^{\circ} / 42.3 \%$ \\
\hline 2 & $80^{\circ}$ & $46^{\circ}$ & $34^{\circ} / 42.5 \%$ \\
\hline 3 & $82^{\circ}$ & $40^{\circ}$ & $42^{\circ} / 51.2 \%$ \\
\hline 4 & $62^{\circ}$ & $50^{\circ}$ & $12 \% / 19.4 \%$ \\
\hline 5 & $80^{\circ}$ & $66^{\circ}$ & $14^{\circ} / 17.5 \%$ \\
\hline 6 & $114^{\circ}$ & $72^{\circ}$ & $42^{\circ} / 36.8 \%$ \\
\hline 7 & $90^{\circ}$ & $57^{\circ}$ & $33^{\circ} / 36.7 \%$ \\
\hline 8 & $112^{\circ}$ & $92^{\circ}$ & $20 \% / 17.9 \%$ \\
\hline 9 & $78^{\circ}$ & $62^{\circ}$ & $16 \% / 20.5 \%$ \\
\hline 10 & $70^{\circ}$ & $40^{\circ}$ & $30^{\circ} / 42.9 \%$ \\
\hline 11 & $104^{\circ}$ & $70^{\circ}$ & $34^{\circ} / 32.7 \%$ \\
\hline 12 & $60^{\circ}$ & $54^{\circ}$ & $6 \% 10.0 \%$ \\
\hline 13 & $94^{\circ}$ & $74^{\circ}$ & $20^{\circ} / 21.3 \%$ \\
\hline 14 & $80^{\circ}$ & $40^{\circ}$ & $40^{\circ} / 50.0 \%$ \\
\hline 15 & $74^{\circ}$ & $48^{\circ}$ & $26^{\circ} / 35.1 \%$ \\
\hline 16 & $62^{\circ}$ & $16^{\circ}$ & $46^{\circ} / 74.2 \%$ \\
\hline
\end{tabular}

Table 3. Cobb measurements after the final distraction performed in each patient, postoperative follow-up time, and final correction.

\begin{tabular}{|c|c|c|c|c|c|}
\hline Patient & $\begin{array}{l}\text { Preoperative } \\
\text { Cobb }\end{array}$ & $\begin{array}{c}\text { Cobb } \\
\text { after final } \\
\text { distraction }\end{array}$ & $\mathbf{N}$ & $\begin{array}{c}\mathrm{T} \\
\text { (months) }\end{array}$ & $\begin{array}{c}\text { Final } \\
\text { correction }\end{array}$ \\
\hline 1 & $104^{\circ}$ & $100^{\circ}$ & 5 & 31 & $4^{\circ} / 3.8 \%$ \\
\hline 2 & $80^{\circ}$ & $50^{\circ}$ & 7 & 47 & $30 \% / 37.5 \%$ \\
\hline 3 & $82^{\circ}$ & $56^{\circ}$ & 3 & 25 & $26^{\circ} / 31.7 \%$ \\
\hline 4 & $62^{\circ}$ & $58^{\circ}$ & 6 & 49 & $4 \% 6.4 \%$ \\
\hline 5 & $80^{\circ}$ & $62^{\circ}$ & 4 & 34 & $18^{\circ} / 22.5 \%$ \\
\hline 6 & $114^{\circ}$ & $74^{\circ}$ & 3 & 22 & $40^{\circ} / 35.1 \%$ \\
\hline 7 & $90^{\circ}$ & $66^{\circ}$ & 8 & 61 & $24 \% / 26.7 \%$ \\
\hline 8 & $112^{\circ}$ & $95^{\circ}$ & 2 & 27 & $17 \% / 15.2 \%$ \\
\hline 9 & $78^{\circ}$ & $62^{\circ}$ & 0 & 0 & $16^{\circ} / 20.5 \%$ \\
\hline 10 & $70^{\circ}$ & $58^{\circ}$ & 1 & 5 & $12 \% / 17.1 \%$ \\
\hline 11 & $104^{\circ}$ & $92^{\circ}$ & 4 & 21 & $12^{\circ} / 11.5 \%$ \\
\hline 12 & $60^{\circ}$ & $56^{\circ}$ & 3 & 19 & $4 \% 6.7 \%$ \\
\hline 13 & $94^{\circ}$ & $80^{\circ}$ & 1 & 9 & $14 \% 13.9 \%$ \\
\hline 14 & $80^{\circ}$ & $45^{\circ}$ & 2 & 13 & $35 \% / 43.7 \%$ \\
\hline 15 & $74^{\circ}$ & $60^{\circ}$ & 1 & 6 & $14 \% 18.9 \%$ \\
\hline 16 & $62^{\circ}$ & $16^{\circ}$ & 0 & 0 & $46^{\circ} / 74.2 \%$ \\
\hline
\end{tabular}

N: Number of distractions; T: Time of postoperative follow-up.

Table 4. Average values obtained in the study.

\begin{tabular}{c|c}
\hline & Average value \\
\hline Preoperative Cobb & $84.1^{\circ}$ \\
\hline Immediate postoperative Cobb & $55.4^{\circ}$ \\
\hline Cobb after the final distraction & $64.4^{\circ}$ \\
\hline Average number of distractions & 3.1 \\
\hline Follow-up & 23.1 \\
\hline Initial correction & $28.7^{\circ} / 34.1 \%$ \\
\hline Final correction & $19.7^{\circ} / 23.4 \%$ \\
\hline
\end{tabular}

the formation of granulation tissue and posterior epithelialization with coverage of the implant. In patient 5, junctional kyphosis, a result of inadequate preoperative planning and the implant not properly encompassing the cranial extremity of the curve, was corrected during the first distraction procedure. The flat back phenomenon (correction of lumbar lordosis) observed in patient 7 , due to the insufficient molding of the system rods, was resolved by an additional approach to remold them. In patents 6 and 8 , we had cases of infection of the surgical site, subsequently resolved by means of proper antibiotic 

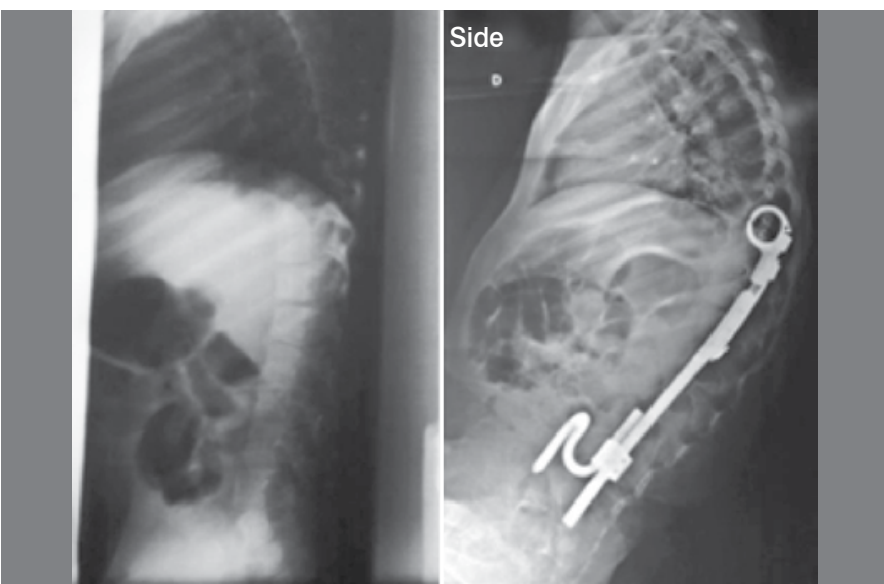

Figure 2. Pre- and postoperative radiographs showing the occurrence of junctional kyphosis.

therapy and surgical debridement. Finally, patient 13 evolved with a profile of respiratory insufficiency and was referred to the Intensive Care Unit for monitoring and was discharged after three weeks.

\section{DISCUSSION}

Early onset scoliosis, defined as that starting prior to 5 years of age ${ }^{9}$ is a spinal deformity with different etiologies in the growing child. Managing it is challenging, with many treatment options, but no conclusive evidence as to which is the best method. ${ }^{5}$

Aiming to avoid the problems associated with spinal fusion in this spectrum of patients, such as lung development deficit and the crankshaft phenomenon, some works in the literature have tried to demonstrate the efficiency of VEPTR as a treatment option for these cases, surpassing other methods that have proved to be limiting. It was initially conceived as a way to maximize thoracic volume in children with thoracic insufficiency syndrome, related to thoracic deformities resulting from rib fusion or hypoplastic thorax such as Jarcho-Levin and Jeune syndromes. ${ }^{10}$ With its success in controlling these deformities, its use was expanded to the correction of scoliotic curves in younger patients by means of successive distractions performed periodically and as needed until completion of the growth of the trunk and skeletal maturity of the patient are reached, at which point the final spinal fusion is performed.

In our case series of 16 patients, starting with an average preoperative Cobb value of $84,1^{\circ}$, we reached an average postoperative Cobb value of $55.4^{\circ}$, i.e., we obtained an average initial correction of approximately $28.7^{\circ}$, equating to a correction of around $34.1 \%$ after only the initial VEPTR implantation, a value close to that of series described in the literature which also sought to show the results of using the VEPTR implant. ${ }^{2,11}$ Later, after the final distraction had been completed for each patient (average: 3.1 distractions, 23.1 months of follow-up), the average final correction was $19.7^{\circ}$, or $23.4 \%$. It is apparent that the initial correction was greater than those of the subsequent distractions and in most cases there was actually a loss of correction ranging from $2^{\circ}$ to $40^{\circ}$, (Figure 3 ) such that the VEPTR appears to behave long term more as an implant to retard the progression of the curves. However, because this study had an average follow-up that could be considered to be short, a question arises as to the long-term maintenance of the correction obtained with the implant, i.e., up until the time when pulmonary and skeletal maturation are reached and the implant can be replaced by the final fusion, i.e. after 10 years of age. This can be addressed by conducting more studies on the theme with longer follow-up periods.

The complications inherent in the use of the VEPTR can be mainly mechanical, infectious, cutaneous, neurological, related to sagittal imbalance, and respiratory, ${ }^{12}$ and are similar to those resulting from the implantation of growing rods even in terms of the complication rate. ${ }^{13,14}$ As already mentioned, in our study the

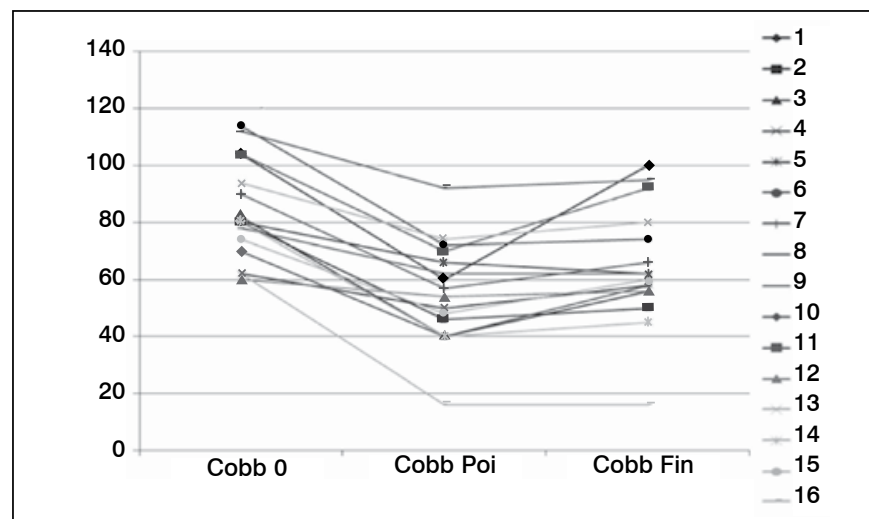

Cobb 0 - Preoperative average/Cobb Poi - Immediate postoperative average/Cobb Fin - Average after the last distraction performed.

Figure 3. Variations in curve magnitude during follow-up.

complication rate inherent in the surgical procedure was $62.5 \%$, with the occurrence of the loosening of the implant due to rib fracture, implant exposure, junctional kyphosis, correction of lumbar lordosis (flat back), infection of the surgical site, and postoperative respiratory insufficiency. In their study, Landin et al. ${ }^{2}$ reported an overall complication rate, associated with VETPR implantations in 17 patients, of $23.5 \%$. In the series of 23 patients in the study by Hasler et al., ${ }^{11}$ this rate was $40 \%$. In their recent French series with 54 patients, Lucas et al. ${ }^{12}$ also observed a complication rate of $40 \%$ and suggested the need for a team trained in implant handling, a preoperative multidisciplinary evaluation of the nutritional and pulmonary conditions of the child, the intraoperative planning of the incisions and the avoidance of incisions over the implant both during placement and in subsequent distractions, care with the molding of the implant to avoid sagittal imbalance, intraoperative monitoring by means of evoked potential, and a multidisciplinary post-operative recovery team in the intensive care unit, as ways to minimize the incidence of complications.

The small universe of patients that we evaluated may explain the greater percentage of complications when compared to larger studies. Family members should be routinely counseled about this greater possibility of complications and the possibility of additional posterior surgical approaches. Future advances in surgical techniques and in the structure of the VEPTR will be focused on reducing complications associated with this method.

\section{CONCLUSION}

Aimed at avoiding problems related to spinal fusion in skeletally immature patients and at allowing initial correction and maintenance of scoliotic deformity until such trunk growth and skeletal maturity have reached a point where final spinal fusion can be performed, VEPTR has emerged as a good option, offering considerable rates of correction. However, perfection of the technique during the implantation itself, as well as in the pre- and postoperative phases, is necessary in order to reduce complication rates that are relatively high with its use. Furthermore, literature about the use of this implant to treat these patients is scarce, indicating a need for more studies with longer follow-up periods to confirm its real efficacy in long-term correction maintenance. In the near future, considering the increasingly widespread use of this technique in centers specialized in spine deformities, more studies will become available in the literature, enabling better conclusions on its results.

All the authors declare that there are no conflicts of interest regarding this article. 
CONTRIBUTIONS OF THE AUTHORS: Each author made significant individual contributions to the development of this manuscript. JPSA was the main contributor to the writing of the manuscript, to the evaluation of the statistical data analysis, and to the bibliographical research. MACF, AFFP, TAMR, RCM, and LTBC performed the surgeries, monitored the patients, collected the clinical data, and reviewed the manuscript. All authors contributed to the intellectual concept of the study.

\section{REFERENCES}

1. Campbell RM Jr, Smith MD, MayesTC, Mangos JA, Willey-Courand DB, Kose N, Pinero RF, Alder ME, Duong HL, Surber JL. The characteristics of thoracic insufficiency syndrome associated with fused ribs and congenital scoliosis. J Bone Joint Surg Am. 2003;85(3):399-408.

2. Landim E, Cavali PTM, Santos MAM, Pasqualini W, Boechat RCB, Andrade SMS. Uso da prótese vertical expansível de titânio para costela (VEPTR) como opção na instrumentação sem fusão para tratamento da escoliose neuromuscular. Coluna/Columna. 2008;7(2):160-6.

3. Harrington PR. Treatment of scoliosis. Correction and internal fixation by spine instrumentation. J Bone Joint Surg Am. 1962;44:591-610.

4. Akbarnia BA, Marks DS, Boachie-Adjei O, Thompson AG, Asher MA. Dual growing rod technique for the treatment of progressive early-onset scoliosis: a multicenter study. Spine (Phila Pa 1976). 2005;30(Suppl 17):S46-57.

5. Smith JT. Bilateral rib-to-pelvis technique for managing early-onset scoliosis. Clin Orthop Relat Res. 2011:469(5):1349-55

6. Campbell RM Jr, Smith MD, MayesTC, Mangos JA, Willey-Courand DB, Kose N, et al. The effect of opening wedge thoracostomy on thoracic insufficiency syndrome associated with fused ribs and congenital scoliosis. J Bone Joint Surg Am. 2004;86(8):1659-74.

7. Suzuki N, Watanabe K. Crankshaft phenomena following spinal fusion in the growing child. In: Akbarnia BA, Yazici M, Thompson GH, editors. The growing spine: management of spinal disorders in young children. New York: Springer-Velag; 2011. p. 393-6.

8. VEPTR II -Vertical Expandable Prosthetic Titanium Rib II:Technique guide: Synthes Spine $\mathrm{Co}^{\circledR}$ 2002/2010. Disponivel em: http://synthes.vo.Inwd.net/o16/LLNWMB8/INT\%20Mobile/Synthes\%20International/Product\%20Support\%20Material/legacy_Synthes_PDF/036.000.733.pdf

9. Gillingham BL, Fan RA, Akbarnia BA. Early onset idiopathic scoliosis. J Am Acad Orthop Surg. 2006:14(2):101-12.

10. Campbell RM Jr, Smith MD, Hell-Vocke AK. Expansion thoracoplasty: the surgical technique of opening-wedge thoracostomy. Surgical technique. J Bone Joint Surg Am. 2004;86(Suppl 1):51-64.

11. Hasler CC, Mehrkens A, Hefti F. Efficacy and safety of VEPTR instrumentation for progressive spine deformities in young children without rib fusions. Eur Spine J. 2010;19(3):400-8.

12. Lucas G, Bollini G, Jouve JL, de Gauzy JS, Accadbled F, Lascombes P, et al. Complications in pediatric spine surgery using the vertical expandable prosthetic titanium rib: the French experience. Spine (Phila Pa 1976). 2013;38(25):E1589-99

13. SankarWN, Acevedo DC, Skaggs DL. Comparison of complications among growing spinal implants. Spine (Phila Pa 1976). 2010;35(23):2091-6.

14. Akbarnia BA, Emans JB. Complications of growth-sparing surgery in early onset scoliosis. Spine (Phila Pa 1976). 2010;35(25):2193-204. 